\title{
First report of Pittosporum cryptic virus 1 in Pittosporum tobira in Lebanon
}

\author{
Raied Abou Kubaa ${ }^{1}$ (D) Pasquale Saldarelli ${ }^{1} \cdot$ Basem Attar $^{2} \cdot$ Fouad Jreijiri $^{3} \cdot$ Elia Choueiri $^{3}$
}

Received: 9 August 2019 / Accepted: 15 November 2019/Published online: 6 December 2019

(C) Società Italiana di Patologia Vegetale (S.I.Pa.V.) 2019

Keywords Pittosporum tobira $\cdot$ Pittosporum cryptic virus-1 $\cdot$ Lebanon $\cdot$ RT-PCR $\cdot$ PiCV1

Pittosporum tobira or Japanese pittosporum is an ornamental greenhouse plant widely used in landscaping and along roadsides, as well as in parks and gardens. In Lebanon, symptoms of chlorotic vein banding were observed on six plants of $P$. tobira growing in two gardens located in the Beqaa Valley. A total of 48 samples were randomly collected from several sites in the Beqaa Valley, including the two gardens. Samples were tested by DAS-ELISA (Loewe, Germany) for the presence of eggplant mottled dwarf virus and tomato spotted wilt virus. None of these two viruses was detected in the collected samples. Then, total RNA was extracted from six symptomatic and six symptomless plants and tested by RT-PCR for the presence of Pittosporum cryptic virus 1 (PiCV1), a recently described double stranded RNA virus that belongs to the genus Deltapartitivirus in the family Partitiviridae (Elbeaino et al. 2016). Two pairs of specific primers were designed based on the available sequence in GenBank (accession number LN680393): [PiCV1-cpF: (5'TGGCAGCATTACCG AAGGTT3') and PiCV1-cpR: (5'TGTGTCGGCAATCA AAGGGA3')] to target a $279 \mathrm{bp}$ fragment of the coat protein gene, and [PiCV1-rdrp637: (5'ACTCGCACACAACT

Raied Abou Kubaa

raied.aboukubaa@ipsp.cnr.it

1 CNR Istituto per la Protezione Sostenibile delle Piante, via Amendola 122/D, 70126 Bari, Italy

2 International Center for Agricultural Research in the dry areas (ICARDA), Bashir El Kasar street, Verdun, 1108-2010, P.O. Box 114/5055, Beirut, Lebanon

3 Department of Plant Protection, Lebanese Agricultural Research Institute, Tal Amara, P.O. Box 287, Zahlé, Lebanon
AACGGA3') and PiCV1-rdrp1008: (5'CGGTGCTG CCACCTTCTTAT3')] to target a 372 bp of the RNAdependent RNA polymerase gene in RT-PCR. DNA amplicons were obtained from the six symptomatic plants while no amplification was observed from the six symptomless plants. To verify the nature of the DNA products, three RT-PCR amplicons were sequenced. BLAST analyses revealed 9899\% nucleotide identity with the Italian isolate Pit-MAIB in both amplified genes and 99-100\% similarity among the Lebanese isolates. Sequences of the Lebanese isolates were deposited in GenBank as accession numbers LR735543LR735544. To the best of our knowledge, this is the first report of PiCV1 in P. tobira in Lebanon. Partitiviruses have been mainly associated with cryptic infections in both plants and fungi (Roossinck 2013). PiCV1 was first reported on P. tobira in Italy. Although cryptic viruses have no known vectors and are not transmitted mechanically or by grafting, they are vertically transmitted at high rates by ovule or pollen (Guy and Gerard 2016). Therefore, PiCV1 has the potential to spread in other Lebanese regions and neighboring countries.

\section{References}

Guy PL, Gerard PJ (2016) White clover cryptic virus-1 in New Zealand and eastern Australia. Ann Appl Biol 168:225-231

Elbeaino T, Abou Kubaa R, Tuzlali HT, Digiaro M (2016) Pittosporum cryptic virus 1: genome sequence completion using next-generation sequencing. Arch Virol 161(7):2039-2042

Roossinck MJ (2013) Plant virus ecology. PLoS Pathog 9(5): 9-11. doi: 10. 1371/journal.ppat. 1003304

Publisher's note Springer Nature remains neutral with regard to jurisdictional claims in published maps and institutional affiliations. 